\title{
«... og vi som skulle gifte oss!»
}

\author{
Medisinsk avdeling ba om tilsyn fra intensivavdelingen til en pasient i begynnelsen av 30-årene. Han hadde \\ kreft og var i terminal fase. Hvilke farmakologiske tiltak kunne være aktuelle?
}

Jeg snakket med pasienten og vurderte om det fantes noen nye behandlingsmuligheter. På en stol like innfor døren, i en slags forgang, satt en ung kvinne og gråt. Jeg hilste på henne. Hun presenterte seg som samboer og mor til deres to måneder gamle barn. Plutselig utbrøt hun: «Og vi som skulle gifte oss!» Jeg fikk forståelsen av at det skulle skje bare noen uker senere. Pasienten kunne ikke høre denne samtalen. Mitt inntrykk etter undersøkelsen var at pasienten sannsynligvis ikke vil rekke å bli utskrevet.

Noe fikk meg til å si at det er jo mulig å splitte selve vielsen fra festen. Gjennomføre vielsen på sykehuset og ta festen når situasjonen var blitt bedre. Jeg sa at vi hadde en hyggelig og dyktig sykehusprest som kanskje var tilgjengelig. Det lot seg sikkert ordne i morgen, sa jeg. Etter å ha tenkt et øyeblikk, la jeg til at kanskje vi like godt kunne få det gjort samme kveld.

Vi ble enig om at jeg skulle ringe sykehuspresten. Klokken var rundt 18, og jeg traff presten hjemme. Han skulle selvsagt stille, men det var et problem med at de måtte ha attestasjon fra folkeregisteret.

Tilbake til samboeren med beskjed om at presten kunne stille, men det var et problem med denne attesten. Hun sa at de ventet på papirer fra folkeregisteret. Dette var jo et tilbakeslag.

Plutselig kom jeg på at jeg kjente en dame på ligningskontoret, som også hadde ansvar for folkeregisteret. At det var lør- dagskveld, fikk være det samme. Kontakt ble opprettet per telefon. Hun opplyste at datasystemene var stengt $i$ helgen slik at hun ikke kunne reise ned og sjekke det. Hadde det vært mulig, så skulle hun gjort det. Etter avtale med samboeren oppga jeg navnet, og damen på folkeregisteret kunne da opplyse at hun husket at papirene var kommet dagen før. Hun skulle ordne det med en gang mandag morgen.

Jeg orienterte så samboeren om dette og ringte presten. Spørsmålet var om han kunne gjennomføre vielsen basert på slike annenhåndsopplysninger. Presten hadde i mellomtiden forsøkt å få råd fra andre i situasjonen. Uten å ha fått kontakt med noen sa presten at det kunne kanskje være mulig at vielsen kunne gjennomføres med forbehold om at attesten ble fremlagt $i$ ettertid. Han sa imidlertid at opplysningen om at papirene var kommet, var godt nok.

\section{Bryllup og dåp}

Påny orientering til samboeren. Hun ble svært glad. Vi ble enig om at det var på tide å innvie den vordende ektemann i planene. Vi gikk sammen inn på rommet og sa at han skulle gifte seg den kvelden. Frem til da hadde han ligget med lukkede øyne som $i$ en døs. Han snudde seg, festet blikket og sa at han måtte dusje og få på seg ny skjorte. Kroppsholdning og blikket gjennomgikk en dramatisk endring.

Neste post var å gå ut på avdelingens dagligstue hvor den øvrige familie og svigerfamilie var samlet. Bestemor passet på det lille barnet. Da jeg - kledd i hvitt - kom inn i rommet, ble det helt stille. «Det skal arrangeres bryllup her i kveld,» sa jeg. Et lettelsens sukk gikk gjennom rommet. Familien sa at de alle hadde tenkt på at han ikke ville rekke det planlagte bryllupet, men ingen hadde tort å si noe, fordi det ville være å signalisere at familien hadde gitt opp håpet.

Presten kom, og det ble rigget opp et alter inne på rommet. Pleiepersonalet stilte som vitner. Øvrige familie var til stede da vielsen ble gjennomført k1 22. Da vielsen var gjennomført, sa pasienten: «Og nå skal vi ha barnedåp. » Dette var ikke avtalt på forhånd, men ble gjennomført.

Pasienten døde tirsdagen etter.

Pårørende har gitt tillatelse til at artikkelen offentliggjøres.

\section{Rune Arild Larsen}

rune.larsen@helse-forde.no

Rune Arild Larsen (f. 1960) er spesialist i anestesiologi og arbeider som seksjonsoverlege ved Intensivavdelingen, Førde sentralsjukehus.

Mottatt 15.9. 2012 og godkjent 27.9. 2012. Medisinsk redaktør Erlend Hem. 